\title{
Where Credit is due: on the Puerto Rican Debt Crisis
}

\author{
Eric Joshi, Amogh Joshi \\ Narayan Gardens, Gujarat, India \\ eric.joshi7@gmail.com,amogh2101@gmail.com
}

\begin{abstract}
This paper provides a comprehensive breakdown of the ongoing economic crisis in the Commonwealth of Puerto Rico. It explores the backdrop of the crisis by analyzing Puerto Rico's relationship with the U.S., macroeconomic indicators and pertinent legislations. It's entirely unique contribution is the analysis of the newly introduced act- PROMESA, which enables Puerto Rico to restructure its debt. We have provided an explanation of the important sections of this legislation which govern the debt negotiation process. The PROMESA act has been extended to apply to other unincorporated territories of the United States as well should they run into arrears, which broadens the scope of this paper. We have extended the findings of pre-existing body of work on sovereign debt restructuring hurdles and explained how PROMESA addresses them. We have also used previous works to suggest measures to expedite Puerto Rico's debt restructuring process with creditors. This paper could also serve as a handbook for creditors looking to navigate through the post-PROMESA debt restructuring process.
\end{abstract}

\section{Keywords: PROMESA, Debt Restructuring}

\section{Introduction}

The Puerto Rican Debt Crisis is an ongoing financial crisis related to the amount of debt owed by the Government of Puerto Rico. It has already defaulted on portions of its debt including millions on May 2, 2016. On July 1, it defaulted on an additional $\$ 2$ billion including $\$ 800$ million of constitutionally backed General Obligation debt. The then Governor of Puerto Rico, Alejandro García Padilla issued a debt moratorium halting payments on all debt obligations which has resulted in litigations and the investment done is at risk. The President of United States of America, at the end of June 2016 signed into law the Puerto Rico Oversight, Management and Economic Stability Act (PROMESA) which seeks to address the lack of legal framework available to the territory and extends its net to all the territories of the US, should they ever default. The move to install a control board comes after US Supreme Court decision on a case, Puerto Rico vs Franklin California Tax-Free Trust, which found a previous attempt by Puerto Rico to restructure its debt, unconstitutional. This decision ended any illusion Puerto Rico had of economic sovereignty. Left with no alternative, the Puerto Rico will have to make-do with the legal framework now provided by the United States Government. The legal framework, the PROMESA bill creates a seven-member panel and is tasked with bringing more than $\$ 70$ billion public debt under control. The board also has broad sweeping powers to reconfigure Puerto Rico's financial and economic policy. The board will be able to facilitate binding negotiations with creditors and, if needed, a court-supervised restructuring. Amidst all this, the recent Zika outbreak in Puerto Rico has exacerbated the bundle of responsibilities on the Puerto Rican Government. Add that with the galvanizing political movement that has called the board, "Colonial Outrage". A popular slogan is on the lips of protestors and activists - "CARAJO LA JUNTA". A delicate situation has arisen on the island. This research paper seeks to shed light on the new legal framework -Oversight Board established under the PROMESA bill and the role that board members must play in helping the island out of the financial crisis.

An Overview of the Puerto Rican Economy and Macroeconomic Indicators: Like most other developing economies Puerto Rico's major economic sector was agriculture in the early $20^{\text {th }}$ century. The key economic drivers today are manufacturing; ensued by the service industry i.e. finance, insurance, real estate, and tourism. The World Bank classifies Puerto Rican economy as a high income economy. Puerto Rico's economy remains closely tied to that of the United States. This is because Puerto Rico is an unincorporated territory of the United States, decided after the Supreme Court's Insular Cases that defined the relationship as "A territory appurtenant and belonging to the United States, but not a part of the United States within revenue clauses of the Constitution". Broadly speaking, the territorial economy is influenced by three things.

Firstly, and most importantly is the legislation pertaining to the island, be it monetary or fiscal policy directed by the Congress: The Jones Act made all inhabitants of the territory a United States citizen. The key 
features of this Act include establishment of bill of rights, power to the residents to elect a Governor for a term of four years and exempting Puerto Rican bonds from federal taxes, state taxes as well as local taxes. We shall see in the later part of the paper how this piece of legislation has shaped Puerto Rican economy and created hurdles albeit unwittingly. The Merchant Marine Act created problems for the island as the ships had to first go through U.S. ports before heading to Puerto Rico. This resulted in inflated costs of goods brought to the island, consequently affecting tourism and the island ability to compete with other Caribbean islands. Congress amended the Internal Revenue Code under which Sec. 931 was replaced with sec. 936. Its aim was to promote economic growth on the island by giving companies tax exemptions thereby incentivizing corporations to invest and manufacture in Puerto Rico. Axiomatically, Puerto Rico experienced dramatic growth from 1950s leading up to the mid '70s. Economic indices indicate a growth rate comparable to the well-known, pronounced growth of East Asia. The massive increase in GDP per worker in 1980 made Puerto Rico one of the "world's most developed Latin societies" (Velez-Hagan, 2015). Section 936 became unpopular in the early 1990's as many saw this as a way for large corporations to avoid paying taxes. Section 936 was then phased out, over a ten-year period, fully repealed in 2006. The subsequent elimination of this tax exemption also contributed and co-relates to a slump in the territorial economy.

Secondly, the economic shocks felt by the mainland had direct and perhaps greater effect on Puerto Rican economy: The 1973-75 recessions in the mainland due Oil Crisis and the 1980's energy crisis's effects lasted longer on the island than compared to the mainland. According to a Banco Bilbao Vizcaya Argentaria (BBVA) report, it costs Puerto Rico an estimated $\$ 750$ million for a mere $\$ 10$ increase per barrel of oil imported, decreasing the Puerto Rican GDP. "According to the American Enterprise Institute, a $\$ 10$ per barrel increase also eats away a half percentage point off the global gross domestic product (GDP)" (McPhaul, 2005).The economic boom in the 1990's helped the economy to recover but at the turn of millennium the island suffered a decade-long contraction, relying for the major part, on transfer payments and other public assistance from the U.S. It is clear from Figure 1 that the economic shocks felt by the mainland were in turn felt by the island. This makes it imperative to remark that the "free association" that Puerto Rico has with United States leaves to island's economy vulnerable to the mainland's economy. It is clear from above that the mainland economy and the policies implemented by them played a role in boosting growth in Puerto Rico up to the top and the economic shocks received by the mainland were in turn felt by them.

Lastly, the internal policies and politics have played a crucial role in shaping the Puerto Rican Economy: The Government has spent considerable amount of their capital on building infrastructure, waterworks and roadways. These development projects have lacked proper estimates and the Government has routinely taken short term loans to cover the costs that shot out from the misleading estimates. In an attempt to jumpstart the economy, which began contracting earnestly back in 2006 , the government went on a spending spree to build new infrastructure that would create new jobs, increase connectivity that would lead to greater labor mobility. However, this ambitious drive lacked accountability in general and inefficient use of capital has resulted in a massive debt that the government cannot make interest payments without cutting key government services like healthcare, education and public safety. “Garcia Padilla administration's ties to political fundraisers haven't truly broken into the mainstream media. Hernandez, along with nine other Puerto Rican businessmen and officials, was arrested in December 2015 as part of an ongoing FBI corruption investigation into Padilla's government" (Mazzella, 2016). These and other such widespread allegations of graft and corruption, over decades, have inflamed the already volatile economic conditions on the island.

The doubling of oil prices from 2005-12 inflated their cost for power generation. The increased cost of import, amounting to 3 percent of GNP increase in oil bill could have been used by the Government to support its local economy (Figure 2). Another factor to the debt crisis in Puerto Rico is that of the real estate crash in 2013. Due to the decade long recession and the heavy debt on the government, few want to buy a house in the island. Since Puerto Ricans are United States citizens, many are simply packing up and moving to mainland (Figure 3). Puerto Rico ranks $2^{\text {nd }}$ for homes in foreclosure in the United States. This trend is likely to continue and more homes will enter foreclosure process seeing how people are choosing to leave the island and move to mainland. The Federal Minimum Wage is applicable to the island making it mandatory to pay the federal minimum wage of $\$ 7.25$ an hour in spite of the island's economy being vastly different from mainland's economy. As shown in the Figure 4, the Federal Policy of Labor is making people in Puerto Rico unemployable 
- a result visible from the territories' unemployment rate is 12.4 percent that is twice more than the 5.5 percent of the mainland.

Higher minimum wages increases cost of hiring for businesses thereby reducing employment. Puerto Rico, which has the ratio of minimum wage to the median wage of 77 percent - 24 percentage points higher than Florida which has the highest minimum wage in United States of America. The local regulations which relate to overtime, paid vacation are costlier than the mainland. Fewer jobs for the people mean fewer taxpayers and more dependency on welfare and public services. These contribute to additional government spending (Figure 5).Outmigration is on the rise due shrinking job opportunities. The Planning Board's projection of population till 2020 continues to fall at negative 1 percent per year. This data, as shown in Figure 6, does not take into account additional economic problems that may occur during/after debt restructuring. Apart from the decrease in demand from the island, the labor force will continue to shrink unless major initiatives are undertaken to curb this activity. The energy costs have fallen with the falling oil prices but cost per hour kilowatt is several times higher than that of the mainland. This raises the cost of locally produced goods and subsequently growth of economic sectors. Due to the higher cost of goods and services, the island finds it hard to compete with other Caribbean islands. The public enterprise (PREPA) uses old technologies and is inefficient. Cost of energy and water supply problems have flared up, discouraging numerous companies and industries from moving their operations in Puerto Rico.

\section{The distinctive Puerto Rican Problem}

Before we dive into a discussion regarding the possible ways of debt relief and restructuring, it is imperative that we take a look at the issues which make solving the Puerto Rican debt crisis a unique problem. The island of Puerto Rico has been a U.S. Territory since 1898 and Puerto Ricans have become U.S. citizens since 1917. Politically, Puerto Rico is an unincorporated territory of the United States, which means that it does not enjoy the privileges of being a state. This has historically divided the people of the island and been a subject of four referendums so far, the latest of which took place on November 6, 2012, which resulted in a slender majority of the populace asking for a complete statehood, some asking for sovereignty and the others wishing to stick with the status quo. The most important economic implication of the "unincorporated territory" status is the unavailability of the option to resort to the Chapter 9 bankruptcy code. "Chapter 9 is a bankruptcy proceeding that provides financially distressed municipalities with protection from creditors by creating a plan between the municipality and its creditors to resolve the outstanding debt. Municipalities include cities, counties, townships and school districts" ("Investopedia", n.d.).

Basically Chapter 9 is the provision to restructure the debt but since territories are not included in the Chapter 9's definition of municipalities, this option remains unavailable to Puerto Rico. The woes of the Commonwealth being unable to restructure its debt is further compounded by the following clause under Article VI (General Provisions) Section 8 of the Puerto Rican Constitution: "In case the available revenues including surplus for any fiscal year are insufficient to meet the appropriations made for that year, interest on the public debt and amortization thereof shall first be paid, and other disbursements shall thereafter be made in accordance with the order of priorities established by law." Thus the General Obligation bonds issued by Puerto Rico take precedence in terms of getting paid first before any other government expenditures including other bonds. This is ensured by the "clawback provision" which means redirecting revenues to pay for the bonds guaranteed by the government of Puerto Rico. The clawback provision came to attention especially when, in December 2015, "Governor Alejandro Garcia Padilla signed an executive order to permit the redirection of revenue budgeted for highway and convention center bonds and other agencies to pay for debt issued or guaranteed by the commonwealth" (Kaske, 2015). However temporary fixes like these served as nothing more than ominous indicators of the inevitable financial peril that was looming large over the island.

To cut down on public spending hundreds of schools have been closed down in the past half-decade making it increasingly difficult for students to find a school nearby while some bus companies have declined service to students for lack of finances. Hospitals and emergency wards are also suffering from lack of funds resulting into power outages. "At least 629 cases of Zika infection have been confirmed, and it is projected that up to 20 percent of the Puerto Rican population could become infected this year, according to data from the Centers 
for Disease Control and Prevention" (Calmes, 2016). It is beyond the scope of this paper to discuss the Applied Ethics and philosophical implications of deciding a debt hierarchy to determine if it is more moral, for a state under duress, to pay a General Obligation bond holder or say pension benefits of a retired stateemployee. Although even from a socio-political standpoint it seems difficult to reason how severe austerity measures, ones suggested by the GO bond holders, would result in a long term solution without social unrest.

Deciphering PROMESA: The Puerto Rico Oversight, Management and Economic Stability Act (Hereafter referred to as PROMESA) at first glance has a whiff of being more of a conciliatory document for several special interest groups, creditors unions and the concerned mainland American citizens over having to sponsor a bailout at the taxpayer's expense. A more careful reading of the bill reveals a lot of new features of interest and suggests that the drafters of the legislation have learnt their lessons from the previously bankrupt US Municipalities and also from sovereign debt negotiations. While the bill enjoyed majority bipartisan support in the House of Representatives, where it was introduced, several Democrats and leaders from Puerto Rico expressed their reservations raising the specter of colonialism but begrudgingly supported the bill. Puerto Rico has tried and exhausted every legal option available to restructure its debt and in the wake of losing an important Supreme Court decision on June 13, 2016 over the legality of Recovery Act, which was described by Justice Sotomayor as "the only existing legal option for Puerto Rico to restructure debts", PROMESA seems to be the only resort. The cornerstone of the PROMESA act is the Oversight Board. The Oversight Board has exclusive control to ensure that the Fiscal Plans are enacted and enforced, and that all necessary reforms are undertaken to put the island on a path to access credit markets.

Let's take a look at some of the important sections in this piece of legislation: Under the provisions for membership laid out in Title 1, the Oversight Board shall consist of 7 members. These members shall be appointed by the President from among the nominees provided by various leaders of Senate and House of Representatives as specified. One of the 7 members shall be either the Governor of Puerto Rico or his designee and will act as an ex officio member with no voting rights. The unavailability of voting rights to the island's representative might be to ensure that the Oversight Board remains neutral in coming up with a plan which is in 'the best interest of the creditors'. The voting members of the Board amongst themselves shall designate one member to act as Chair. After this the Oversight Board shall formulate bylaws, rules and procedures governing it under this act. The Oversight Board will have an Executive Director appointed by the chair. The Executive Director and the personnel hired by him shall be paid for their services while the members of the Oversight Board will only be compensated for the expenses incurred while serving. It is interesting to note that an island battling with economic crisis has a Board imposed on it, the expenses of which will be borne by the island's already heavily indebted Treasury (Hacienda). It is also apparent that instating an Oversight Board which performs the same task that a similarly empowered Puerto Rican Government would have done is redundant. However, an obvious positive impact of putting a Federal Oversight Board in charge would be a boost in the creditor confidence as the Board is tasked with passing balanced Fiscal Plans while also ensuring the best possible outcome for the creditors.

Section 210. It is imperative to note from the onset that an act drafted and passed by the United States House of Representatives, Senate and the President of United States, clearly and unequivocally, under Sec. 210, distances the US from pledging full faith and credit for "the of any principal of or interest on any bond, note, or other obligation issued by the territory or territorial instrumentality". (PROMESA of 2016). While Puerto Rico's economic future is in the hands of a Board, constituted by the United States and vested with sweeping powers, the responsibility clearly doesn't fall at the doorstep of the United States Federal Government.

Section 104(e). One of the clauses, conspicuous by its presence not in a limiting manner but as an enabler is a glaring loophole so obvious it is almost euphemistic to call it one. The Section 104 - Powers of Oversight Board, allows its members "to accept, use, and dispose of gifts, bequests, or devises of services or property, both real and personal, for the purpose of aiding or facilitating the work of the Oversight Board". (PROMESA of 2016). It is difficult to comprehend why the drafters of the legislation would feel the need to allow for this provision as it is not too difficult to see a potential conflict of interest arising out of this. It would seem worth noting at this juncture that the members of the Oversight Board only get reimbursed for their expenses and are not paid for their services. 
Section 405(b) (1)-Automatic Stay upon Enactment. This section ensures that upon the enactment of PROMESA the creditors cannot seek injunctive action against Puerto Rico or its instrumentalities. This will provide some major breathing room for the commonwealth and the Oversight Board as it seeks to restructure the island's debt. The automatic stay has already undergone its first test as Plaintiffs Brigade Leveraged Capital Structures Ltd. and two others approached the District Court of Puerto Rico to revoke the stay under Sec.405(e) and to challenge the constitutionality of the Moratorium Act but were shot down by the presiding judge who upheld the stay. This stay remains in effect until February 15, 2017 but could be extended by the Oversight Board's discretion under Sec.405 (d).

Section 405(j) - No Default Under Existing Contracts. This states that as long as the stay applies, no bearer of a liability claim can seek remedy based on contractual implication or applicable law. This closes another door for the creditors and forces them to come to the table for negotiations. "The term remedy here has a broader perspective which includes the right to- setoff, apply or appropriate funds, seek the appointment of a custodian (as such term is defined in section 101(11) of 9 title 11, United States Code), seek to raise rates or exercise control over property of the Government of Puerto Rico" (PROMESA of 2016).

Section 407(a) Protection from Inter-Debtor Transfers. The said section provides some comfort to the creditors and also discourages the kind of avoidance behavior that got the island into the current economic debt in the first place. Under Sec. 407(b) the creditor is given the right to enforce action via the District Court against any state instrumentalities, in case of violation, after the stay period is over.

Section 405(1). This assures the creditors that as long as the Oversight Board deems "it is feasible the Government of Puerto Rico shall make interest payments on outstanding indebtedness when such payments become due during the length of the stay" (PROMESA of 2016). The powers of the District Court have also been limited under PROMESA. Under Sec. 305 the court cannot, without the Oversight Board's consent, "interfere with- (1) any of the political or governmental powers of the debtor; (2) any of the property or revenues of the debt; or (3) the use or enjoyment by the debtor of any income-producing property". It is apparent that the Oversight Board has a Herculean task in front of it by the fact that under Title 2, it has the responsibility to both- provide adequate funding for public pension systems and respect the relative lawful priorities or lawful liens, as may be applicable, in the constitution. The Oversight Board is seeking to "create a firewall between the constitutionally protected creditor hierarchy and pensions in the development of Fiscal Plans".

Section 104(i) Voluntary Agreement Certification. Under this section, the territory or the covered instrumentality can enter a voluntary accord with the bearers of its bond claims to restructure its bond claims. This certification depends on whether a Fiscal Plan has been validated by that point in time or not. In case a Fiscal Plan has been certified then the Oversight Board has to take into account if the plan provides for a sustainable debt for the territory or its covered instrumentality. In case a Fiscal Plan has not been certified then it will be the Oversight Board's sole discretion to certify if the plan provides for sustainable debt level of debt. Notwithstanding the above conditions, certification will also be provided "if an applicable Fiscal Plan has not yet been certified and the voluntary agreement is limited solely to an extension of applicable principal maturities and interest on Bonds issued by Puerto Rico or territorial instrumentality" (PROMESA of 2016). This applies, for a time frame of up to one year on the Bond Claims during which interest won't be paid on claims on which a voluntary agreement is reached.

Section 601 Creditor Collective Action. This section entails the Oversight Board to consult the issuer and separate the bonds into pools as follows:

- "Not less than one Secured Pool for which a revenue stream has been pledged and separate pools for bonds of different priorities" (PROMESA of 2016). For the bonds which have no revenue stream pledged a separate pool shall be made.

- "The Administrative Supervisor shall not place into separate Pools Bonds of the same Issuer that have identical rights in security or priority" (PROMESA of 2016).

- "For each Issuer that has issued multiple Bonds, for at least some of which a guarantee of repayment has been provided by the Territory Government Issuer, separate Pools shall be established for such guaranteed and non-guaranteed Bonds"(PROMESA of 2016). 
Apart from the certification of the Oversight Board as discussed above, a modification also needs to be submitted to the holders of the respective debt instruments by specified channels of communication. The qualifying modification must be consented to by the majority of the holders of outstanding principal amount in the pool and voted affirmative by at least $2 / 3 \mathrm{rd}$ of the Principal amount that is outstanding of the Outstanding Bonds in each Pool. If the modification passes successfully through these steps, the qualifying modification shall be presented to the United States District Court. The Court has the power to nullify the modification "if and only if the district court determines that such Modification is manifestly inconsistent with this section" (PROMESA of 2016). Once the modification receives the court's nod on having followed all the steps listed in the Section, the modification becomes binding even on those creditors that have expressed dissent. The binding nature of the modification ensures that there is no room for creditor holdout. There can be no further litigations by dissenting creditors once a qualified modification is passed by the specified majority of the creditor pool, consented by the territory, certified by the Oversight Board, and approved by the judiciary. This also helps speed up the negotiations required to restructure the debt.

Section 602. Perhaps to quell the debate around international agencies like IMF potentially playing some role in Puerto Rico's debt crisis on account of it being a territory, the penultimate Section 602 of the legislation makes it clear that "Federal, State, or territorial laws of the United States, as applicable, shall govern and be applied without regard or reference to any law of any international or foreign jurisdiction." (PROMESA of 2016).

Negotiations with Creditors in post PROMESA world: Renegotiating debt can sometimes be very prolonged lasting for more than 10 years. It is important to understand various issues that prolong the renegotiation process. The economy of Puerto Rico, already down to its knees does not have the time for lengthy and protracted negotiations. Time is on Puerto Rico's side as the debt restructurings now, on average take significantly less time than back in 1980's and 1990's (31 months) vs "Post Brady Era" (17 months). Argentina's bond instrument re-issuing (which included global investors) in 2005 and Serbia's 2004 exchange of bank debt are the only exceptions that took more than 3 years to negotiate. Let us take a look at hurdles in restructuring process listed and explained by Das, Papaioannou, and Trebesch (2012).

\section{Hurdles in Restructuring Process}

Creditor coordination failures, litigation, and holdouts: "Problem of creditor holdouts and litigation is widely seen as the main reason for delayed and inefficient debt restructurings. Creditor holdout scenario is when a creditor refuses to participate in a restructuring offer, so as to enforce better terms later" (Das, Papaioannou, and Trebesch, 2012, p.28).This is seen a major obstacle in creditor coordination failure, "mainly due to the shift from bank to bond financing in emerging markets. Intuitively, large bondholder groups may find it harder to coordinate and agree on a deal, compared to a small group" (Das, Papaioannou, and Trebesch, 2012, p.28).However, with the Oversight Board overseeing the debt-restructuring process, the Puerto Rican Government should make use of the Board Members' expertise so that the problem of coordination is solved. Although Title 6 of the PROMESA takes care of litigations that can happen after a restructuring deal is negotiated, provided that the set procedure of debt-negotiation was followed, one needs to be alert nonetheless.

Debtor policies and political risk: "In addition to creditor behavior, it is well known that debtor country policies, or in this case territorial policies, lack of transparency and insufficient communication with creditors, can contribute to failed or delayed restructuring processes" (Das, Papaioannou, and Trebesch, 2012, p.29). This issue is well addressed within PROMESA. For instance, Under Title 6 Sec. 601, there is provision for an Information Agent for each creditor pool for effective communication. Title 6 Sec. 601 Subsection (D), also establishes well defined creditor pools, ensuring a concrete structure to enable creditorpool specific plans and effective communication. The legally binding nature of these modifications ensures maximum creditor participation during the negotiation stages. In addition to this, the Oversight Board demands from the Puerto Rican Government to have certified fiscal and budgetary plans. If well executed, this could cut the time it takes to negotiate a new deal significantly. "All available evidence indicates that information sharing and closes consultations with banks and bondholders go hand in-hand with quick and successful restructuring. A frequent issue of disagreement is the disclosure of reserve amounts or of details 
on prospective exchange offers. Creditors can, in Puerto Rico's case ask for relevant information from the Oversight Board" (Das, Papaioannou, and Trebesch, 2012, p.29).

The disputes on non-disclosed debt buyback programs cannot happen here as all the negotiations have to follow a set procedure according to section 601 and the plan has to be certified by the Oversight Board which then proceeds to court to make it legally binding. These checks and balances ensure to almost utmost certainty that creditors will not have to deal with non-cooperation from the debtors. While the task of seeing that Debtor policies do not interfere with the negotiations process falls on both the Oversight Board and the Puerto Rican Government, the onus of maintaining political stability falls squarely on the territorial government. Political instability and political economy problems play a role in increasing the time it takes to negotiate a restructuring. Elections, conflicts, widespread riots and general strikes, or the resignation of key government members can all cause delays in implementing a debt restructuring. Puerto Rico gubernatorial elections which were held on November 8, 2016 led to the election of Ricardo Rossello, a pro-statehood candidate as the Governor of Puerto Rico. The political parties have a crucial role to play in maintaining the political stability of the region. The winning party must undertake conscientious policy planning to correct the deep rooted structural problems that lie in their economy rather than inciting friction and spouting rhetoric.

Retail Investors Vs Institutional Investors: While designing an exchange offer, the Government of Puerto Rico should keep in mind the type of investors they are dealing with. A range of exchange options allows investors to "choose among different new instruments when tendering their old claims, thus accounting for differing preferences across creditors. Retail investors tend to prefer new bonds with no face value reduction and are more willing to accept long maturity and low coupons" (Das, Papaioannou, and Trebesch, 2012, p.23) Institutional investors prefer to go for bonds with a reduction in principal with a combination of shorter maturities and higher coupons. Accordingly, the government should take into account the type of investors that have invested in their bonds and design an exchange offer accordingly.

Debt-sustainability: While debt-negotiations in progress, the debtor in order to achieve high participation rate, contain "carrot" features or "sweeteners" "that generate incentives for participation. Sweeteners can take the form of upfront cash repayments, advantageous legal features of the new bonds, or add-ons to the new instruments which may include higher interest rates"( Das, Papaioannou, and Trebesch, 2012, p.22) The Government needs to thoroughly assess the feasibility of providing high interest rates on the new bonds and "how much". This will include a careful scrutiny of revenue streams and the amount of liabilities. A step up in interest payments may bring the creditors on board the negotiations and successful restructuring would mark the end of crisis episode because the exchange of old into new debt instruments puts the country back on the path of debt sustainability."However, restructurings do not always put an end to debt distress. Some countries continue to incur arrears after a completed restructuring process and there are many examples in which sovereigns implemented a series of subsequent restructurings" (Das, Papaioannou, and Trebesch, 2012, p.13). Thus, the Puerto Rican Government will have to carefully gauge how much interest they can offer on the new bonds so as the debt remains "sustainable".

\section{Conclusion}

This paper has endeavored to lay down the present economic condition of the island of Puerto Rico and provide a backdrop of the federal as well as territorial economic and legislative reasons as to why the commonwealth finds itself in the said condition. We have traced several usual macroeconomic indicators that are important in a distressed economy but especially pointed out indicators like the rate of migration, labor participation rate, minimum and median wages as compared to states, and how federal legislation like the Jones Act and Section 936 have affected Puerto Rico as a territory. We believe that with the passing of PROMESA act, both the creditors and the debtors have entered the uncharted territory of debt negotiations. We have analyzed this new piece of legislation which has bearing upon not just the case at hand but is a bankruptcy code for other unincorporated territories of the US as well. We have attempted to point out the unique features of this act and the concerns that it addresses and the ones it does not. We believe that the members appointed to the Oversight Board have to perform a tough balancing act between managing the $\$ 70$ billion debt and continuing to fund the island's $\$ 43$ billion in pension liabilities. It is important for the 
Oversight Board to recognize that while Fiscal Plans need to be balanced, too many budget cuts might be impractical if not from a moral, from an economic standpoint because when all's said and done, the American citizens of Puerto Rico need the basic public facilities and perhaps even more with a Zika outbreak on their hands. Some political leaders and concerned protesters have voiced the opinion that the Oversight Board raises a specter of colonialism for the island but after a careful reading of the legislation and comparing it with the pitfalls commonly experienced in debt negotiations, we believe that PROMESA is the best possible outcome for Puerto Rico, at the moment, to remove significant hurdles during and after the debt restructuring process. The legislation alone does not guarantee its success; the 7 board members appointed to the Oversight Board must act in a bipartisan manner to ensure that normalcy returns to the island's institutions and its people.

We have analyzed past trends of sovereign debt negotiations to make pertinent suggestions to Puerto Rico and its bond issuing institutions about the ways to expedite the process and to ensure debt sustainability. It will be of great interest to see how the members of the Oversight Board co-ordinate with the Puerto Rican government and with the creditors to fulfill their daunting task. Only once the Oversight Board members are appointed and the negotiations begin, will us able to see in earnest how the legislation of PROMESA translates into action. How the inhabitants of the island react to the Oversight Board's decisions and what effects PROMESA has on the debate surrounding the island's political status in the future remains to be seen. We wish the Puerto Rican government a smooth debt restructuring process for the fate of an island and its entire people depends upon it.

\section{References}

Calmes, J. (2016). Treasury Secretary Jacob Lew Puts a Face on Puerto Rico Debt Crisis. NY

Times.http://www.nytimes.com/2016/05/10/business/dealbook/treasury-secretary-jacob-lew-puts-a-faceon-puerto-rico-debt-crisis.html?_r=0

$\begin{array}{lllllll}\text { Chapter 9- DEFINITION of 'Chapter 9'. Investopedia. (n.d.) Retrieved } & \text { of }\end{array}$ fromhttp://www.investopedia.com/terms/c/chapter9.asp

Das, U. S., Papaioannou, M. G. \& Trebesch, C. (2012). Sovereign Debt Restructurings1950-2010: Concepts, Literature Survey, and Stylized Facts. IMF Working Paper.

Kaske, M. (2015). Puerto Rico Avoids Default by Redirecting Revenue From Bonds. Bloomberg.https://www.bloomberg.com/news/articles/2015-12-01/puerto-rico-to-avoid-defaultby-making-december-bond-payments

Krueger, A.O., Teja, R. \& Wolfe, A. (2015). Puerto Rico- A Way Forward.

Mazzella, J. (2016). Puerto Rico's Untold Tale of Corruption. CFIF.http://cfif.org/v/index.php/commentary/43-taxes-and-economy/2990-puerto-ricos-untoldtale-of-corruption

McPhaul, J. (2005). Rising oil prices. How high they going and what are the options? Caribbean Business.

Puerto Rico Oversight, Management, and Economic Stability Act of 2016, 48 USC § 2150.

Puerto Rico Oversight, Management, and Economic Stability Act of 2016, 48 USC § 2124.

Puerto Rico Oversight, Management, and Economic Stability Act of 2016, 48 USC § 2194.

Puerto Rico Oversight, Management, and Economic Stability Act of 2016, 48 USC § 2231.

Puerto Rico Oversight, Management, and Economic Stability Act of 2016, 48 USC § 2232.

Puerto Rico GDP Annual Growth Rate (2016). Trading Economics. Retrieved fromhttp://www.tradingeconomics.com/puerto-rico/gdp-growth-annual

Velez-Hagan, J. (2015). Puerto Rico's Economy: A brief history of reforms from the 1980s to today and policy recommendations for the future. NPR Chamber.http://nprchamber.org/files/3-19-15-Puerto-RicoEconomic-Report.pdf. 


\section{Appendix}

Figure 1: Puerto Rico GDP annual growth rate

PUERTO RICO GDP ANNUAL GROWTH RATE

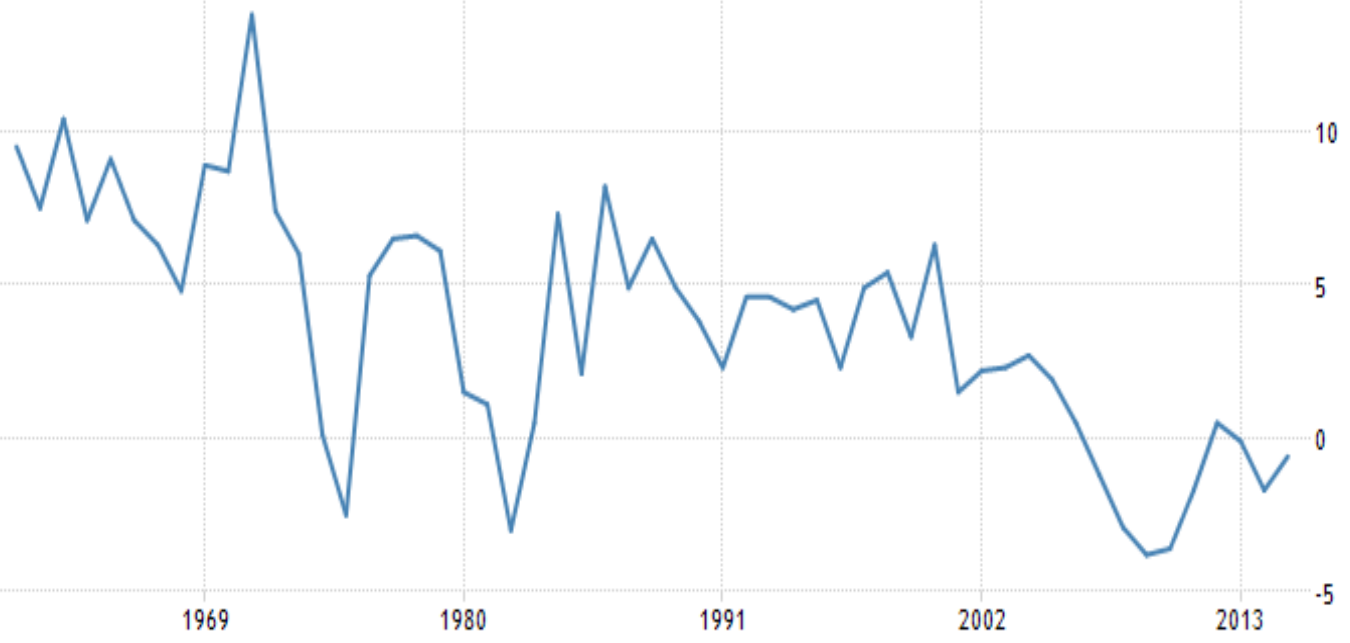

SOURCE: WWW.TRADINGECONOWICS.COW I STATISTICAL INSTITUTE OF PUERTO RICO

Source: www.tradingeconomics.com.

Figure 2: Oil imports by Puerto Rico from 2005 to 2015 and oil prices during those years

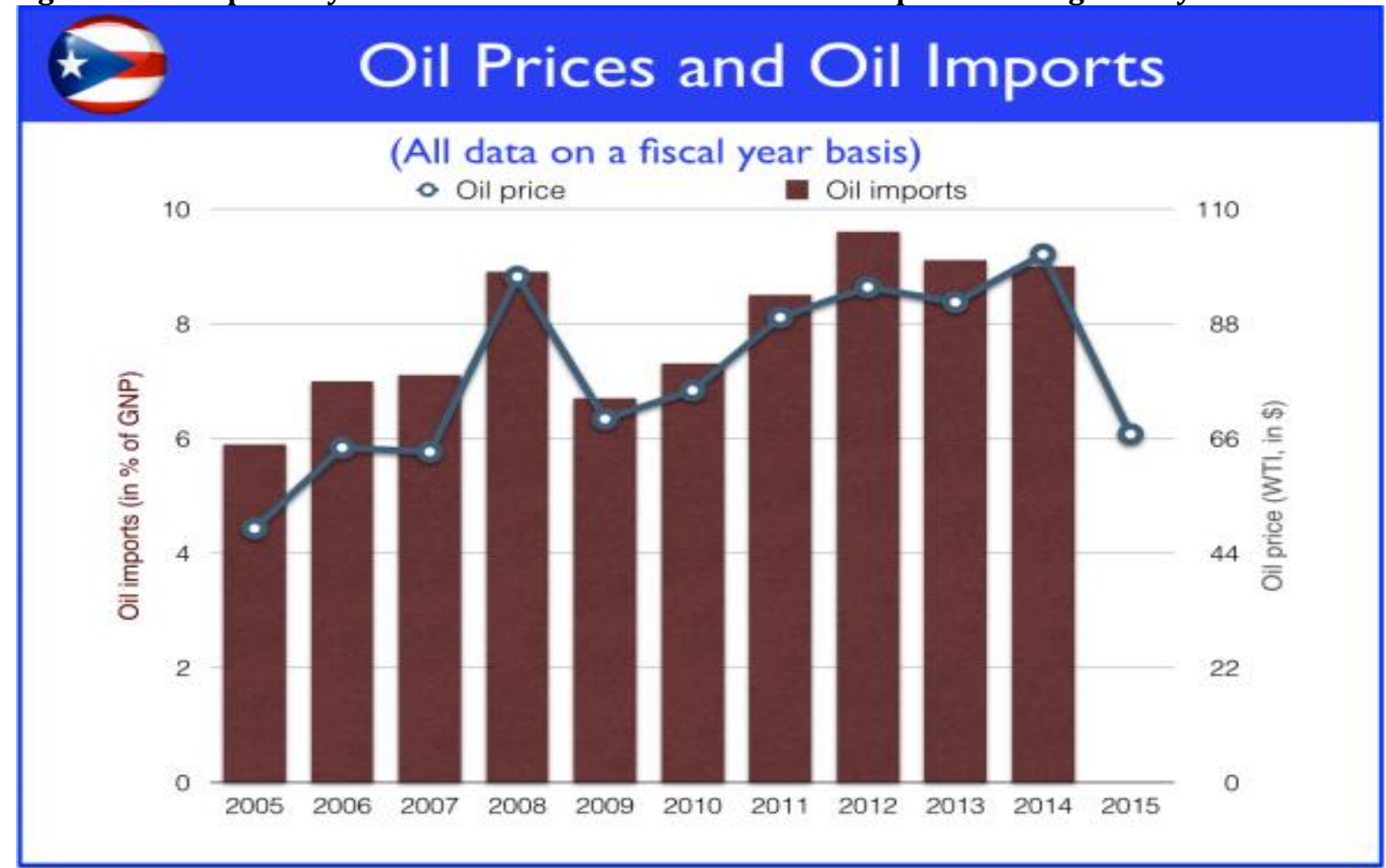

Source: "Puerto Rico- A Way Forward” by Krueger, A.O., Teja, R., and Wolfe A. 
Figure 3: Investment Collapse (in \% of GNP) from 2004-2014 and House Price collapse from 20052014

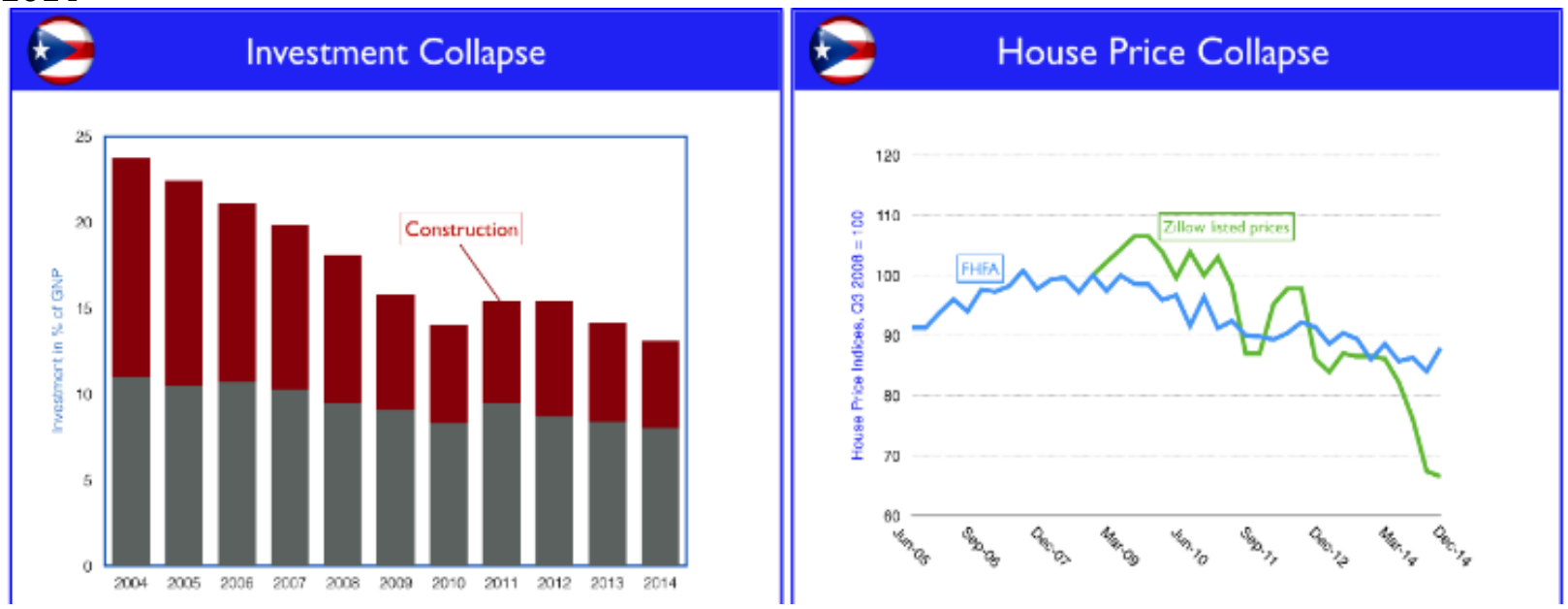

Source: "Puerto Rico- A Way Forward" by Krueger, A.O., Teja, R., and Wolfe A.

Figure 4: Minimum Wage as a Percent of Median Wage. Comparison between Puerto Rico and American States

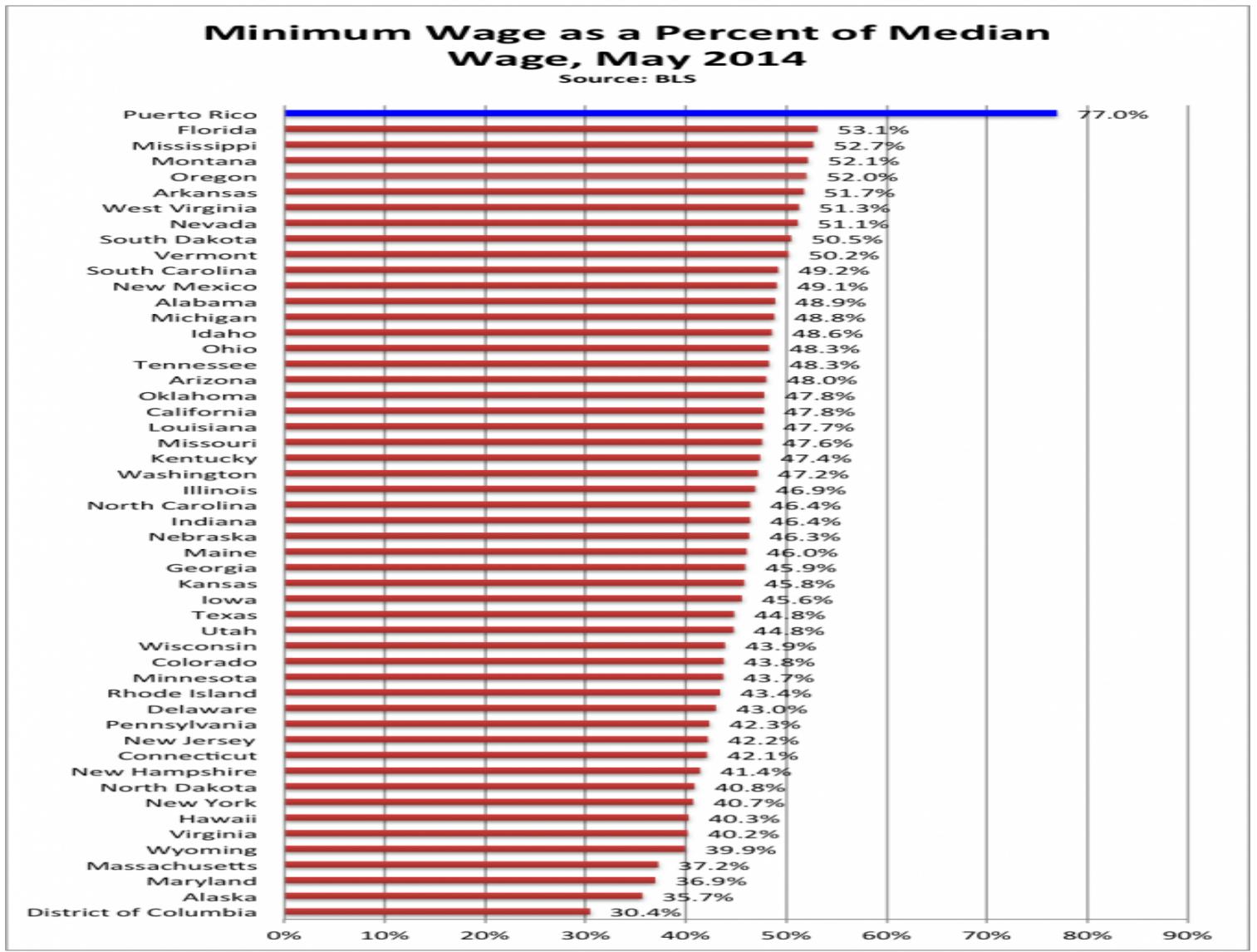

Source: "Puerto Rico- A Way Forward" by Krueger, A.O., Teja, R., and Wolfe A. 
Figure 5: Declining Labor Participation Rate owing to massive unemployment benefits and other reasons.

\section{Labor Participation Rate}

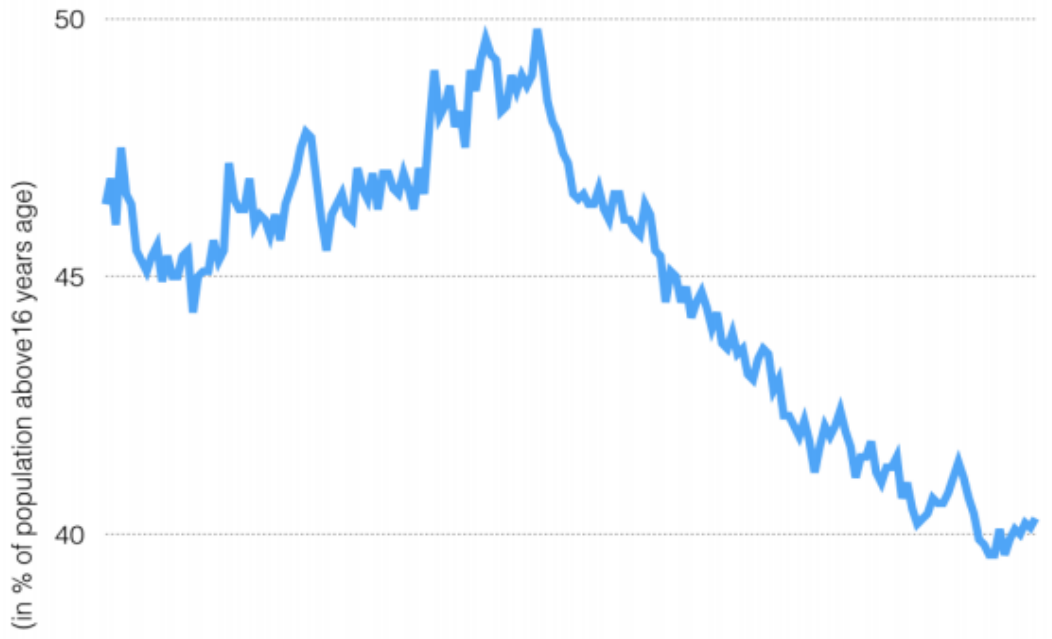

35

2000M2 2004M2 2008M2 2012M2 2015M3

Source: "Puerto Rico- A Way Forward" by Krueger, A.O., Teja, R., and Wolfe A.

Figure 6: The Decline in Puerto Rican Population and Projected Decline

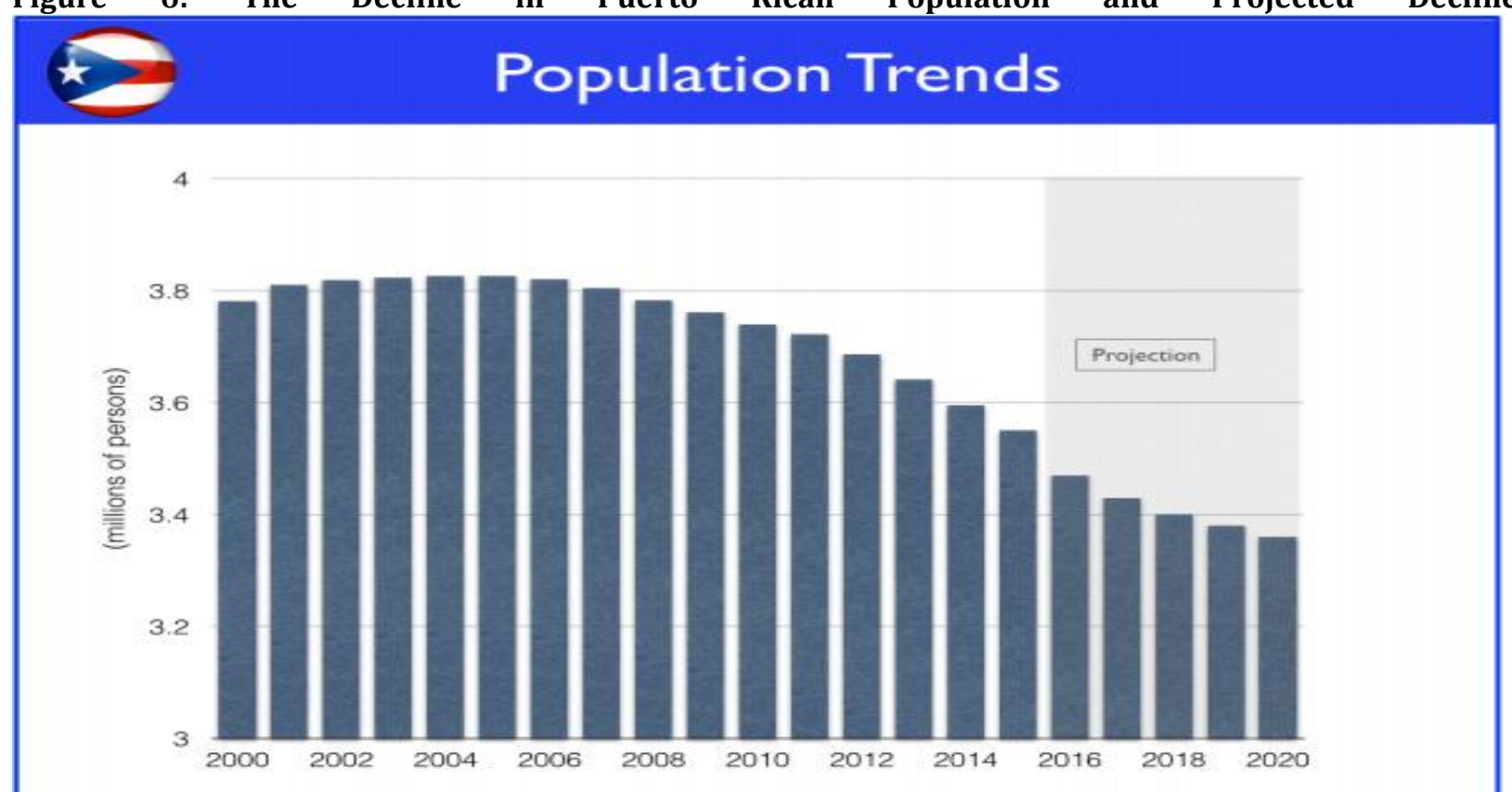

Source: "Puerto Rico- A Way Forward" by Krueger, A.O., Teja, R., and Wolfe A. 